\title{
Helicobacter pylori: From infection to cure
}

\author{
ABR THOMSON MD PhD FRCPC FACG
}

\begin{abstract}
ABR ThOMSON. Helicobacter pylori: From infection to cure. Can J Gastroenterol 1996;10(3):167-172. Over 380 abstracts, presentations and posters of recent advances were highlighted at the European and International Helicobacter pylori meeting held July 7 to 9, 1995 in Edinburgh, Scotland. New advances abound, with major interest focusing on the simple, safe, inexpensive new 'gold standard' for H pylori eradication therapy: a single week of tid omeprazole $20 \mathrm{mg}$, metronidazole $400 \mathrm{mg}$ and clarithromycin $250 \mathrm{mg}$, or omeprazole $20 \mathrm{mg}$, amoxicillin $1000 \mathrm{mg}$ and clarithromycin 500 mg. To avoid false negative results, two biopsies must be taken from the antrum and two from the gastric body at least four weeks after completion of eradication therapy, and ideally should be supplemented with at least one further $H$ pylori test such as a biopsy for urease activity or culture, or a urea breath test. While most patients with a gastric or duodenal ulcer (DU) who do not consume nonsteroidal anti-inflammatory drugs are infected with $\mathrm{H}$ pylori, the association is much less apparent in those with a DU who present with an upper gastrointestinal hemorrhage. H pylori eradication for nonulcer dyspepsia is not widely recommended, and the patient with a DU given effective $H$ pylori eradication who presents with dyspepsia likely has erosive esophagitis rather than recurrent DU or H pylori. Gastroenterologists are at increased risk of H pylori infection, particularly older gastroenterologists who are very busy endoscopists.
\end{abstract}

Key Words: Adenocarcinoma, Eradication, Helicobacter pylori, Mucosa-associated lymphoid tissue (MALT) lymphomas, Peptic ulcer disease

\section{Helicobacter pylori : de l'infection à la guérison}

RÉSUMÉ : Plus de 380 résumés, présentations et affiches sur les récentes percées accomplies dans le domaine ont été présentés dans le cadre d'une récente conférence européenne et internationale sur Helicobacter pylori, tenue du 7 au 9 juillet 1995 à Edimbourg, en Écosse. Les nouvelles percées sont nombreuses, mais le principal intérêt portait surtout sur un nouvel étalon-or simple, sûr et peu coûteux pour le traitement d'éradication de $H$. pylori : une seule semaine d'un schéma t.i.d. d'oméprazole $20 \mathrm{mg}$, métronidazole $400 \mathrm{mg}$, clarithromycine $250 \mathrm{mg}$ ou oméprazole $20 \mathrm{mg}$, amoxicilline $1000 \mathrm{mg}$ et clarithromycine $500 \mathrm{mg}$. Pour éviter les résultats faussement négatifs, deux biopsies doivent être prélevées à partir de l'antre et deux à partir du corps de l'estomac, au moins quatre semaines après la fin du traitement d'éradication et idéalement, confirmées par au moins un autre test de dépistage de $H$. pylori, comme une biopsie pour vérifier l'activité de l'uréase ou une culture ou la mesure de l'urée respiratoire. Si la plupart des patients atteints d'ulcères gastriques ou duodénaux qui ne prennent pas d'anti-inflammatoires non stéroïdiens sont infectés à $H$. pylori, l'association est beaucoup moins évidente chez les patients souffrant d'un ulcère duodénal qui présentent une hémorragie des voies digestives supérieures. L'éradication de $H$. pylori en présence de dyspepsie non ulcéreuse n'est pas très recommandée et le patient souffrant d'un ulcère duodénal qui reçoit un traitement d'éradication efficace contre $H$. pylori et qui souffre de dyspepsie présente probablement une oesophagite érosive plutôt qu'un ulcère duodénal récurrent ou une infection à $H$. pylori. Les gastro-entérologues sont exposés à un plus grand risque d'infection à $H$. pylori, surtout les gastro-entérologues plus âgés qui effectuent beaucoup d'endoscopies.

From the European Helicobacter pylori Study Group and the VIIIth International Workshop on Gastro-duodenal Pathology and Helicobacter pylori held July 7 to 9, 1995 in Edinburgh, Scotland

Division of Gastroenterology, University of Alberta, Edmonton, Alberta

Correspondence: Dr ABR Thomson, University of Alberta, 519 Robert Newton Research Building, 11315-87 Avenue, Edmonton, Alberta

T6G 2C2. Telephone 403-492-6490,fax 403-492-7964, e-mail alan.thomson@ualberta.ca

Received for publication July 21, 1995. Accepted August 21, 1995 
$\mathrm{R}$ ecent advances, presented at the European and International Helicobacter pylori meeting held July 7 to 9 , 1995 in Edinburgh, Scotland, are highlighted, including the new 'gold standard' for $H$ pylori eradication therapy. Topics discussed are the epidemiology and transmission of $\mathrm{H}$ pylori, bacterial pathogenic factors, ulcer pathogenesis (gastritis and gastrointestinal physiology), gastric cancer and lymphoma, diagnosis of human infection and trials resulting in a new standard for eradication therapy.

\section{EPIDEMIOLOGY AND TRANSMISSION: THE HOST}

$H$ pylori is viable in water, and its mode of transmission may be fecal-oral in developing countries or oral-oral in developed countries. The rate of $H$ pylori acquisition in Finland has declined; it was higher in cohorts born in 1926 or 1936 than in those born in 1946 or 1956, supporting the hypothesis that $H$ pylori infection and subsequent gastritis are mainly acquired in childhood (1).

While $H$ pylori infection is a predominant cause of duodenal ulcers (DU), in persons presenting with bleeding DU, H pylori infection is less common (2). The reason for this difference is unknown, but it highlights two important clinical points. First, while DU in a person not taking nonsteroidal anti-inflammatory drugs (NSAIDs) and not bleeding may be taken as likely proof of an $\mathrm{H}$ pylori infection, in a patient with bleeding DU, care must be taken to determine whether $H$ pylori infection is present. Second, and in keeping with the American National Institutes of Health consensus guidelines, because of the high risk of recurrent ulceration with hemorrhage, patients with bleeding DU need to be considered for maintenance acid-lowering therapy to prevent further potentially dangerous complications.

As gastroenterologists, must we be concerned about our potential risk of developing H pylori? Yes - the prevalence of $H$ pylori in gastroenterologists in France increases with age, from $18.7 \%$ at age 30 to 34 years to $55.3 \%$ at age 55 to 59 years (3). When stratified by age group, the prevalence of $H$ pylori infection increases with the number of endoscopies performed by senior physicians (3).

\section{THE ORGANISM: BACTERIAL PATHOGENIC FACTORS}

Most $H$ pylori strains implicated in peptic ulcers and gastric cancer produce a vacuolating cytotoxin and an immunodominant cytotoxin-associated protein encoded by the vacA and cagA genes, respectively (4). The vacA S1a signal sequence is more common in DU patients. CagA strains are associated with a higher bacterial load, and more inflammation, erosions and cytokine production, ie, cagA is a marker for proinflammatory events. If $c a g \mathrm{~B}$ (pic $\mathrm{A}$ ) or $\operatorname{cagC}$ ( pic $\mathrm{B}$ ) are knocked out, there is less interleukin (IL)-8 production. Many $H$ pylori strains from asymptomatic carriers produce neither vacA nor cagA protein. An approximately $21 \mathrm{~kb} s e g-$ ment present only in cagA+ strains (cagII, second cytotoxin-associated gene segment) has been found (5). Specific vacA signal sequence types are associated with the ability of $\mathrm{H}$ pylori strains to cause DU and gastric ulcers (GU), and with the degree of gastric inflammation these strains induce (6). A second essential virulence factor is H pylori adhesion to gastric epithelial cells, and $H$ pylori strains from DU patients are both more adhesive and more cytotoxic than strains from patients with chronic gastritis (7). HspA is a groES homologue in $\mathrm{H}$ pylori of 118 amino acids with a unique carboxy-terminus that is more common in $\mathrm{H}$ pylori-infected individuals with gastric cancer than in those with atrophy $(8)$.

$\mathrm{H}$ pylori survives in acidic $\mathrm{pH}$ in the presence of urea but does not survive at neutral $\mathrm{pH}$ depending on the urea concentration. Gene expression of H pylori is strongly regulated in response to environmental changes such as $\mathrm{pH}$ and urea, indicating that gastric acid and urea play an important role in the physiology and, therefore, survival of $H$ pylori in acid (9).

\section{ULCER PATHOGENESIS}

Gastritis: Large gastric folds seen radiologically or endoscopically may result from infectious, inflammatory, infiltrative or ischemic disorders involving part or all of the gastric wall. H pylori gastritis is associated with mucosal edema as well as infiltration of the mucosa and submucosa with neutrophils, eosinophils, microphages and lymphocytes. H pylori infection is a common cause of thickened gastric folds, and after eradication therapy the thickening shown by endoscopic ultrasound resolves (10).

Rarely, seroconversion of $H$ pylori occurs $(0.6 \%$ per annum), causing the spontaneous disappearance of the $H$ pylori-associated chronic gastritis (11).

$H$ pylori gastritis is associated with a reduction in the depth of the tight junctions and in the number of tight junction strands (12). Chemotactic signals are necessary for local accumulation of granulocytes as a response to acute bacterial infection, and the alterations in tight junctions may be important for this. H pylori up-regulates IL-1-beta and tumour necrosis factor-alpha gene transcription, as well as intercellular adhesion molecule-1 (13).

Using a highly specific and sensitive monoclonal antibody to $\mathrm{H}^{+} / \mathrm{K}^{+}$-ATPase, it has been shown that the prevalence of parietal cells in the duodenal bulk is higher in $H$ pylori-negative recurrent DU patients than in either $H$ pylori-positive DU patients or $\mathrm{H}$ pylori-negative healthy controls (14).

$H$ pylori infection is worse in the antrum, not necessarily because the load is less, but rather because the acid secreted in the gastric body is partially neutralized by the ammonia produced by $\mathrm{H}$ pylori. The proinflammatory effect of the $H$ pylori in the antrum is buffered less by the parietal cellproduced hydrogen chloride and thus inflammation is greater. With any acid-lowering therapy (antacids, $\mathrm{H}_{2}$ receptor antagonists, proton pump inhibitors) there is less acid in the gastric body and antrum, leading to more inflammation. Gastrointestinal physiology: Many people are infected with H pylori but only some develop DU. This may be related, in part, to variations in the strain of $\mathrm{H}$ pylori, but is also partly re- 
lated to differences in the physiological response of the host. Hypochlorhydria develops in patients with chronic atrophic gastritis and acute $H$ pylori infection, while patients who develop $H$ pylori-positive DU will have enhanced basal acid output (BAO), and increased acid output stimulated with gastrin 17, pentagastrin and gastrin releasing peptide (GRP). $\mathrm{H}$ pylori infection results in hypergastrinemia, and its magnitude is similar in those with and without DU. Parietal cell sensitivity to gastrin 17 infusion is increased in $\mathrm{H}$ pylori-positive DU patients and decreased in $\mathrm{H}$ pylori-positive healthy volunteers, compared with $\mathrm{H}$ pylori-positive healthy volunteers (15). The cagA strain does not influence acid secretion. In contrast, there is no difference between $\mathrm{H}$ pylori-positive and $\mathrm{H}$ pylori-negative healthy volunteers in response to the infusion of graded doses of pentagastrin with respect to BAO, maximal acid output (MAO), pentagastrin sensitivity or, near the epithelial interface, postprandial gastrin profile (16).

Hypergastrinemia associated with $H$ pylori infection may be due to an alkaline microclimate resulting from the production of ammonia by $\mathrm{H}$ pylori or to a water-soluble protein released from $H$ pylori (17). Abnormalities in peptidecontaining cells may also be important; infusion of GRP causes a greater increase in plasma gastrin in $\mathrm{H}$ pylori-positive than in $\mathrm{H}$ pylori-negative dyspeptic nonulcer patients, and a greater increase in antral mRNA for gastrin and somatostatin (18). This up-regulation of gene expression may be caused by inflammatory cytokines such as IL-8. Following eradication of $\mathrm{H}$ pylori, the elevated number of antral $\mathrm{G}$ cells persists but the reduced number of antral somatostatin containing D cells returns to normal (19). Because the elevated plasma gastrin falls to normal but the antral $G$ cells remain elevated despite $H$ pylori eradication, $G$ cell sensitivity is presumably altered. In $\mathrm{H}$ pylori-positive nonulcer patients, eradication decreases body gastritis in mRNA, but does not change it in H pylori-positive DU patients (20). Body gastritis is typically present in $\mathrm{H}$ pylori-positive nonulcer patients but is characteristically absent in $H$ pylori-positive DU patients, suggesting that mucosal inflammation affects the expression of somatostatin in $\mathrm{H}$ pylori. This also supports the suggestion that $H$ pylori reduces somatostatin in the antrum, reducing the inhibition on $\mathrm{G}$ cell numbers, thereby leading to hypergastrinemia.

Hypergastrinemia does not occur in all DU patients, possibly because of differences in the infective load of $\mathrm{H}$ pylori $(21,22)$. The relationship between hypergastrinemia and elevated $\mathrm{BAO}$ or $\mathrm{MAO}$ remains unclear because eradication of $H$ pylori normalizes the previous basal and stimulated (integrated) hypergastrinemia in DU patients, but $\mathrm{BAO}$ and MAO remain elevated up to five months later (23). The physiological elevation of gastrin with omeprazole therapy is higher in $\mathrm{H}$ pylori-positive than in $\mathrm{H}$ pylori-negative subjects, suggesting that $H$ pylori-associated inflammation sensitizes the G cell to hypochlorhydria (24).

In $H$ pylori-negative recurrent DU patients, median BAO and peak acid output after pentagastrin or GRP remained high, with the $\mathrm{PAO}_{\mathrm{Pg}}$ in the $\mathrm{H}$ pylori-positive $\mathrm{DU}$ range
(14), suggesting that there may be a subset of DU patients who retain high acid outputs.

\section{GASTRIC CANCER AND LYMPHOMA}

$H$ pylori is classified as a group I carcinogen. Eradication of $H$ pylori results in rapid histological and slower molecular regression of $\mathrm{H}$ pylori-associated low grade gastric mucosaassociated lymphoid tissue (MALT) lymphomas (25). The neoplastic cells in MALT lymphomas may indirectly depend on $H$ pylori stimulation through an autoimmune mechanism (26). CagA is positive in $51 \%$ of patients with MALTomas.

The allele frequency of DQA $1 * 0102$ is higher in $\mathrm{H}$ pylori-negative gastric cancer patients than in gastric cancer patients positive for $H$ pylori (27). While $H$ pylori infection may be associated with severe atrophic gastritis and gastric cancer in high cancer risk ethnic groups, the differences in cancer risk appear to be related more to $H$ pylori infection than to the presence of atrophy (28). Gastric atrophy has epidemiology different from that of $H$ pylori infection, so the $\mathrm{H}$ pylori-atrophic gastritis-gastric cancer link is not straightforward.

H pylori causes chronic inflammation, with increased cell turnover, increased oxygen free radicals and reduced vitamin $\mathrm{C}$ concentrations in gastric juice. These factors are present in $\mathrm{H}$ pylori-infected persons with DU, yet their risk of gastric cancer is fourfold reduced. The number of parietal cells is normal in people with gastric cancer so hypochlorhydria is a functional problem. Thus, it is unclear why some persons with $H$ pylori develop gastric cancer.

Vaccines are being studied for the prevention and clearance of $H$ pylori. Candidates include heat shock proteins, recombinant urease enzyme and vacA. H pylori has evolved to evade the mucosal immune response that accompanies natural infection, but in mice it is possible to convert an ineffective to an effective anti- $H$ pylori immune response by presentation of antigen with mucosal adjuvants such as heat-labile enterotoxin of Escherichia coli (29). Inactive release apoenzyme may have a role as a therapeutic vaccine in the induction of mucosal immunity and clearance of $\mathrm{H}$ pylori infection, at least in a mouse model (30).

\section{DIAGNOSIS OF HUMAN INFECTION}

Although histology is a sensitive method for diagnosis of $H$ pylori infection, it is not specific, and false negative results arise from low numbers of organisms or the development of coccoid forms. When only one biopsy sample was taken from the gastric antrum or body for culture of $H$ pylori, false negatives were seen in approximately $25 \%$ of results at pretreatment (31). In situ hybridization may prove to be additionally sensitive for diagnosis of $H$ pylori, especially when the bacterial load is low (32). There is less H pylori colonization density after acid suppression, after eradication therapy or with the development of atrophic gastritis (33). If only one antral biopsy is used, $10 \%$ of $\mathrm{H}$ pylori infections are missed; if two antral biopsies are used, $5 \%$ of the $H$ pylori infections are missed - the other $5 \%$ are in the gastric body. 
The ${ }^{13} \mathrm{C}$-urea breath test (UBT) is a popular noninvasive method of diagnosing $\mathrm{H}$ pylori infection. The patient does not need to be fasting (34), although some authors suggest that a fatty meal or citric acid be used to delay gastric emptying (35). The labelled area may be given in a capsule to avoid the potential effect of urease-producing bacteria in the oropharynx (36). The magnitude of the UBT or H pylori immunoglobulin $\mathrm{G}$ serology cannot be used to predict the presence or absence of gastroduodenal ulcers (37). The UBT is usually repeated one month after eradication therapy, but may show successful eradication earlier (38).

There are wide differences in the reliability of rapid urease tests. The CLO test (Axcan) and Hpfast test result in an erroneous categorization of $\mathrm{H}$ pylori status for 3\% to $10 \%$ of cases, and the Pylori Tek test may be even less accurate (39). The Helisal whole blood, serum and saliva tests (Axcan) have lower diagnostic accuracy than the ${ }^{14} \mathrm{C}-\mathrm{UBT}(40)$ or serology (41). The Helisal rapid blood test (Axcan) gives a sensitivity of only $88 \%$ to $92 \%(42,43)$.

The prevalence of GU in patients not taking NSAIDs is reported to be lower than that in patients with DU, but when vigorous diagnostic methods are used, such as multiple testing including histology (two from the antrum and two from the body), urease test, culture, UBT or serology, H pylori infection may be as common in GU patients as in DU patients (44). Interestingly, mucosal inflammation in $\mathrm{H}$ pylori-positive dyspeptic patients results in an increased number of blood leukocytes (45).

\section{TRIALS: A NEW STANDARD FOR ERADICATION THERAPY}

The American Food and Drug Administration has recently indicated that $\mathrm{H}$ pylori eradication is an acceptable surrogate for reduced DU and GU recurrence for the purpose of clinical trial designs and for patients not taking chronic NSAIDs (46). The new 'gold standard' for simple (one week of tid therapy), safe and efficacious (at least 95\% H pylori eradication) eradication of $\mathrm{H}$ pylori in patients with DU disease, either active or in remission, has been demonstrated in the Mach 1 multicentre study involving 787 patients. Omeprazole $20 \mathrm{mg}$, metronidazole $400 \mathrm{mg}$ and clarithromycin $250 \mathrm{mg}$, each given bid for one week, or omeprazole $20 \mathrm{mg}$, amoxicillin $1000 \mathrm{mg}$ and clarithromycin $500 \mathrm{mg}$, each given bid for one week, satisfy criteria for optimal treatment of H pylori (47). Similarly high (96\%) H pylori eradication rates were reported from a single centre using the first treatment (48-50). An eradication rate of $94.6 \%$ was reported for omeprazole $20 \mathrm{mg}$ and tinplazole (not available in Canada) 500 mg bid plus clarithromycin $250 \mathrm{mg}$ bid, with the antibiotics given for one week and omeprazole given for one month.

\section{REFERENCES}

1. Sipponen P, Kosunen TU, Heinonen OP, Samloff IM, Siurala M. Rate of $H$ pylori infection in different birth cohorts. Gut 1995;37:A11.

2. Kohl H, Wolters U, Peitz U, et al. Causative role of Helicobacter pylori in upper gastrointestinal bleeding. GUT 1995;37:A28.

3. Broutet N, Cantet F, Lamouliatte H, Forestier S, Megraud F. Seroprevalence of Helicobacter pylori infection among gastroenterologists in France. Gut 1995;37:A78.

4. Beales I, Crabtree JE, Covacci A, Calam J. Antibodies to CAG A
The low dose, inexpensive, one-week Bologna regimen (omeprazole $20 \mathrm{mg}$ daily, metronidazole $400 \mathrm{~g}$ bid, clarithromycin $250 \mathrm{~g}$ bid) and the two-week Bordoux regimen (omeprazole $20 \mathrm{mg}$ bid, amoxicillin $1 \mathrm{~g}$ bid, clarithromycin $500 \mathrm{~g}$ bid) achieve eradication rates of $90 \%$ to $100 \%$, and represent a European standard.

Substituting lansoprazole $30 \mathrm{mg}$ bid for omeprazole, plus amoxicillin $1 \mathrm{~g}$ bid and clarithromycin $500 \mathrm{mg}$ bid for two weeks, gave an eradication rate of $95 \%$ in a small study (21 subjects) (51). About $60 \%$ of patients who fail on omeprazole plus clarithromycin develop clarithromycin resistance. However, in the presence of omeprazole, eradication may still be possible with metronidazole or clarithromycin, despite pretreatment resistance. Resistance can depend on geography; for example, clarithromycin resistance is $0 \%$ in the United States, about 3\% in Britain and 10\% in France.

Lower rates of eradication $(60 \%)$ are seen with dual therapy with omeprazole $20 \mathrm{mg}$ plus amoxicillin $1 \mathrm{~g}$ bid for two weeks $(50,52)$. Less effective eradication regimens may be associated with higher reinfection rates.

Ranitidine bismuth citrate (RBC) is a novel compound with antisecretory, cytoprotective and anti-H pylori properties. Eradication rates of $82 \%$ to $94 \%$ have been obtained with RBC $400 \mathrm{mg}$ bid for four weeks plus clarithromycin $500 \mathrm{mg}$ tid for two weeks (53-55), compared with eradication rates of $68 \%$ to $74 \%$ with RBC $800 \mathrm{mg}$ bid plus amoxicillin $500 \mathrm{mg}$ qds for two weeks followed by RBC alone for two weeks $(56,57)$.

Smoking may (58) or may not (59) reduce eradication rates, and may affect pretreatment resistance to, for example, clarithromycin (60) or metronidazole (61). Smoking may be a risk factor for metronidazole resistance (62).

In dyspeptic patients eradicated of $\mathrm{H}$ pylori infection, recurrent dyspeptic symptoms occurring one to five years following eradication were due to endoscopically proven reflux esophagitis $(9.9 \%)$, and less commonly to $\mathrm{H}$ pylori and DU recurrence $(1.7 \%)(63)$. Is there any proven rationale for eradicating $\mathrm{H}$ pylori in a patient with proven gastroesophageal reflux disease? No, but $H$ pylori-associated gastritis worsens with prolonged acid inhibition, and one can argue that it is important to normalize the mucosa when this infection may be associated with an increased risk of gastric cancer.

Intragastric acidity in patients given omeprazole is greater without than with $H$ pylori infection, ie, $H$ pylori augments the $\mathrm{pH}$-raising effect of omeprazole in DU patients (64). The clinical significance of this observation is unknown. The effectiveness of $\mathrm{H}_{2}$-receptor antagonists at night-time may also be less after $H$ pylori eradication.

protein in patients with $\mathrm{H}$ pylori infection and atrophic gastritis. Gut 1995;37:A37.

5. Akopyants NS, Kersulyte D, Berg DE. CAGII, a new multigene locus associated with virulence in Helicobacter pylori. Gut 1995;37:A1.

6. Atherton JC, Tham KT, Peek RM, Blaser MJ, Cover TL. Specific Helicobacter pylori vacA genotypes are associated with presence of duodenal and gastric ulceration, and degree of gastric inflammation. Gut 1995;37:A3. 
7. Nilius M, Sienla K, Schuppert U, Sauerbruch T, Malfertheiner P. Helicobacter pylori strain variability in adhesion, cytotoxicity and IL-8 release. Gut 1995;37:A3.

8. Perez-Perez GI, Thiberge JM, Labigne A, Blaser MJ. Relationship between the immune response to HSPA and clinical features in Helicobacter pylori-infected patients. Gut 1995;37:A79.

9. Voland P, Melchers K, Schafer KP, Steinhilber W. Regulation of gene expression by $\mathrm{pH}$ and urea in Helicobacter pylori. Gut 1995;37:A2.

10. Avunduk C, Navab F, Hampf F, Coughlin B. Evaluation of large gastric folds in patients with Helicobacter pylori infection by endoscopic ultrasound before and after antimicrobial therapy. Gut 1995;37:A38.

11. Valle J, Kekki M, Sipponen P, Siurala M. The natural history of Helicobacter pylori gastritis: a 30-year histologic follow-up study. Gut 1995;37:A69.

12. Bode G, Mauch F. Ultrastructural evidence for the destruction of gastric epithelial tight junctions by Helicobacter pylori. Gut 1995; 7:A73.

13. Rieder G, Hatz RA, Stolte M, Enders G. mRNA transcript for inflammatory mediators in $\mathrm{H}$ pylori-associated gastritis. Gut 1995;37:A73.

14. Harris AW, Walker MM, Waller JM, Misiewicz JJ, Baron JH. Parietal cells in the duodenal bulb are more common in $\mathrm{H}$ pylori negative patients with duodenal ulcer. Gut 1995;7:A73.

15. Gillen D, El-Omar E, McColl KEL. Parietal cell sensitivity to gastrin distinguishes $H$ pylori infected DU patients from infected healthy volunteers. Gut 1995;37:A8.

16. Hurlimann S, Dur S, Schwab P, et al. Pentagastrin stimulated gastric acid secretion and postprandial gastrin profile in Helicobacter pylori (HP) positive and negative healthy volunteers. Gut 1995;37:A9

17. Hatz RA, Kopp R, Lehn N, et al. Direct enhancement of gastrin release by $H$ pylori water soluble proteins. Gut 1995;37:A9 .

18. Gibbons AH, Legon S, Calam J. H pylori alters the changes in somatostatin and gastrin mRNAs induced by infusion of gastrin releasing peptide. Gut 1995;37:A9.

19. Tham TCK, Chen L, Dennison N, et al. Antral somatostatin cell density and Helicobacter pylori in man. Gut 1995;37:A9.

20. Gibbons AH, Legon S, Calam J. Effect of H pylori on expression of somatostatin mRNA in the gastric antrum and corpus. Gut 1995;37:A83.

21. Isakov VA, Aruin LI, Zverkov IV. Hypergastrinemia is associated with Helicobacter pylori infective load in duodenal ulcer patients. Gut 1995;37:A29.

22. Le Roux PH, Harris AW, Walker MM, Misiewicz JJ, Baron JH. Gastric acid output, bacterial load and gastritis in Helicobacter pylori (Hp) positive patients with duodenal ulcer (DU). Gut 1995;37:A73.23. Gisbert JP, Boixeda D, Vila T, de Rafael L, Alvarex I, Martin de Argila C. Basal and stimulated gastrin levels and gastric acid output five months after therapy for $\mathrm{H}$ pylori eradication in duodenal ulcer patients. Gut 1995;37:A30.

24. Lambert JR, Midolo P, Prichard PJ, Savage J, Bampton P. Helicobacter pylori infection causes increased hypergastrinaemia during omeprazole therapy. Gut 1995;37:A59.

25. Savio A, Granzin G, Wotherspoon AC, et al. Long-term effect of anti-Helicobacter pylori therapy on gastric MALT lymphoma. Histological and molecular evaluation of 15 cases. Gut 1995;37:A6.

26. Karameris A, Rokkas T. Evidence for the role of Helicobacter pylori in the pathogenesis of MALT-type lymphomas of the stomach through an autoimmune mechanism. Gut 1995;37:A76.

27. Azuma T, Hirai NE, Ito S, Kato T, Kohli Y, Kuriyama M. Host's genetic analysis in patients with atrophic gastritis or gastric carcinoma harboring Helicobacter pylori. Gut 1995;37:A7.

28. Graham DY, Malaty FIM, Glober G, et al. Prevalence of gastric atrophy, the precursor lesion of gastric carcinoma, is independent of the prevalence of $\mathrm{Hp}$ infection: evidence that while $\mathrm{Hp}$ infection may be the major determining factor for gastric cancer it is not for gastric atrophy. Gut 1995;37:A7.

29. Buck FJ, Doidge C, Lee A. Therapeutic immunisation - the future for helicobacter treatment? Gut 1995;37:A93.

30. Kleanthous H, Ermak T, Pappo J, Lee C, Monath T. Oral immunization with recombinant Helicobacter pylori urease apoenzyme in the treatment of helicobacter infection. Gut 1995;37:A94

31. Siepman N, Green R, Aynilian G. A comparison of biopsy specimens from the antrum and corpus for culture of $\mathrm{H}$ pylori. Gut 1995;37:A14.

32. Karttunen TJ, El-Zaatari FAK, Genta RM, Yoffe B, Graham DY. Detection of Helicobacter pylori in gastric biopsies by in situ hybridization. Gut 1995;37:A59.

33. Karnes WE, Samloff IM Jr, Siurala M, et al. Positive serum antibody and negative tissue staining for Helicobacter pylori in subjects with atrophic body gastritis. Gastroenterology 1991;101:167-74.

34. Moayyedi P, Axon ATR. Validating of a non-fasting ${ }^{13}$ carbon urea breath test to diagnose Helicobacter pylori (H pylori) infection. Gut 1995;37:A12.

35. Dominguez-Munoz JE, Linke A, Sauerbruch T, Malfertheiner P. A citric acid solution is an optimal test meal in the ${ }^{13} \mathrm{C}$-urea breath test (UBT) for the diagnosis of $H$ pylori infection. Gut 1995;37:A53.

36. Hamlet AK, Erlandsson KIM, Olbe L, et al. A simple, rapid and highly reliable capsule-based ${ }^{14} \mathrm{C}$ urea breath test for diagnosis of Helicobacter pylori infection. Gut 1995;37:A53.

37. Prasad VM, Sharma TK, Cutler AF. Quantitative noninvasive testing for $\mathrm{H}$ pylori does not predict gastroduodenal ulcer disease. Gut 1995;37:A13.

38. Bazzoll F, Zagari RM, Fossi S, et al. The ${ }^{13} \mathrm{C}$-urea breath test for early assessment of Helicobacter pylori eradication. Gut 1995;37:A61

39. Yousfi MM, El-Zimaity H, Cole RA, Genta RM, Graham DY. Commercially available rapid urease tests vary in efficacy for detecting Helicobacter pylori infection. Gut 1995;37:A13.

40. Lahaie RG, Ricard N. Validation of Helisal whole blood, serum and saliva tests for the non-invasive diagnosis of $\mathrm{H}$ pylori infection. Gut 1995;37:A13.

41. Luzza F, Maletta M, Imeneo M, Biancone L, Pallone F. Salivary specific IgG in the diagnosis of Helicobacter pylori infection in dyspeptic patients. Gut 1995;37:A52.

42. Yapp T, Kapur K, Thomas GAO, Swift J, Pugh S. Validation of the Helisal rapid hole blood test for the detection of IgG antibodies to H pylori. Gut 1995;37:A56.

43. Moayyedi P, Carter AM, Heppell RM, Catto AJ, Grant P, Axon ATR. Validation of a rapid whole blood test for the diagnosis of Helicobacter pylori infection. Gut 1995;37:A53.

44. Seppala K, Sipponen P, Nuutinen H, Kosunen TU. Diagnosis of H pylori infection in peptic gastric ulcer. How to do it properly? Gut 1995;37:A58.

45. Karttunen TJ, Niemela S, Kerola T. Blood leukocytes in H pylori infection. Gut 1995;37:A36.

46. Hopkins RJ, Girardi LS, Turney EA. Helicobacter pylori eradication as a surrogate for reduced peptic ulcer recurrence: A literature-based metal-analysis. Gut 1995;37:A46.

47. Lind T, Veldhuyzen van Zanten SJO, Unge P, et al. The Mach 1 study: optimal one-week treatment for $\mathrm{H}$ pylori defined? Gut 1995;37:A4

48. Labenz J, Adamek RJ, Idstrom JP, Peitz U, Tillenburg B, Borsch G. Duodenal ulcer healing and Helicobacter pylori eradication by oneweek low-dose triple therapy with omeprazole, clarithromycin and metronidazole. Gut 1995;37:A41.

49. Buckely M, Xia HX, Hyde D, O'Moraine C. A cost-effective, European approach to $H$ pylori eradication. Gut 195;37:A91.

50. Delchier JC, Elamine I, Goldfain D, Chaussade S, Mancini L, Idstrom JP. Comparison of omeprazole $(\mathrm{OM})+$ Amoxicillin $(\mathrm{AM})$ versus $\mathrm{OM}$ + clarithromycin (CLA) in the eradication of Helicobacter pylori (Hp) - results from a randomized study involving 120 patients. Gut 1995;37:A55.

51. Lamouliatte H, Cayla R, Forestier S, et al. Dual therapy versus triple therapy: high dose of lansoprazole plus amoxicillin in combination or not with clarithromycin for Helicobacter pylori infection. Gut 1995;37:A92.

52. Sung JY, Ling TKW, Suen R, Leung VKS, Ng EKW, Chung SCS. Amoxicillin plus omeprazole versus triple therapy, for the eradication of H pylori and healing of duodenal ulcers. Gut 1995;37:A6.

53. Pounder RE, Bailey R, Louw JA, et al. GR122311X (ranitidine bismuth citrate) with clarithromycin for the eradication of Helicobacter pylori. Gut 1995;37:A42.

54. Peterson WL, Sontag SJ, Ciociola AA, Sykes DL, McSorley DJ, Webb $\mathrm{DD}$ and the $H$ pylori Ulcer Group. Ranitidine bismuth citrate plus clarithromycin is effective in the eradication of Helicobacter pylori and prevention of duodenal ulcer relapse. Gut 1995;37:A5.

55. Bardhan KD, Dallaire C, Eisold H, Duggan AE. The treatment of 


\section{Thomson}

duodenal ulcer with GR122311X (ranitidine bismuth citrate) and clarithromycin. Gut 1995;37:A5.

56. O'Morain C, Schulz TB, Tam C-Y, Dixon MF, Quirke P, Duggan AE. GR122311X (ranitidine bismuth citrate) with amoxycillin for the eradication of Helicobacter pylori. Gut 1995;37:A42.

57. Butruk E, Ching CK, Schutze K, Duggan AE. The treatment of duodenal ulcer with GR122311X (ranitidine bismuth citrate) and amoxycillin. Gut 1995;37:A42.

58. Kusstatscher S, Dal Bo N, Ferrana M, et al. Cigarette smoking and gastritis activity are predicting factors of Helicobacter pylori eradication rate. Gut 1995;37:A47.

59. DeBartolo M, Reltmayer R, Olson C, Edmonds A. Effect of smoking on $H$ pylori (HP) eradication and duodenal ulcer (DU) recurrence in patients receiving dual therapy with clarithromycin (CL) in combination with omeprazole (OM). Gut 1995;37:A85.

60. Calya R, Zerbib F, Talbi P, Megraud F, Lamouliatte H. Pre-and post-treatment clarithromycin resistance of Helicobacter pylori strains: a key factor of treatment failure. Gut 1995;37:A55.

61. Xia HX, Buckley M, Hyde D, Keane CT, O'Morain CA. Effects of antibiotic-resistance on clarithromycin-combined triple therapy for Helicobacter pylori. Gut 1995;37:A55.

62. Lowy A, Dworkin B, Van Horn K, Schwarz SM, Lebovics E, Bennett Clark S. Clinical and endoscopic characteristics of metronidazole resistant Helicobacter pylori. Gut 1995;37:A72.

64. Labenz J, Tillenburg B, Peitz U, Sollbohmer M, Stolte M, Borsch G. Long-term clinical course of ulcer disease and incidence of reflux esophagitis in a large cohort of duodenal ulcer patients followed after eradication of Helicobacter pylori. Gut 1995;37:A6.

64. Labenz J, Tillenburg B, Peitz U, et al. Helicobacter pylori augments the $\mathrm{pH}$-raising effects of omeprazole in duodenal ulcer patients. Gut 1995;37:A8. 


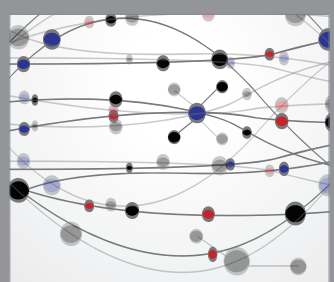

The Scientific World Journal
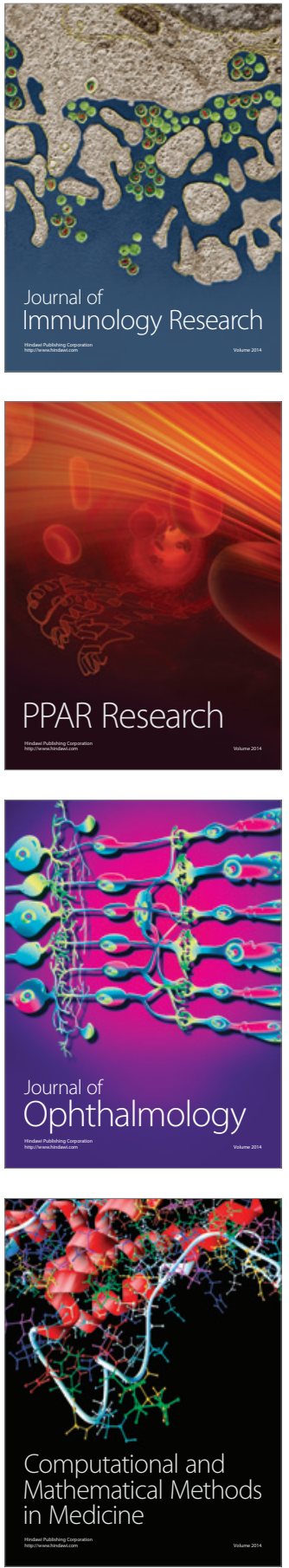

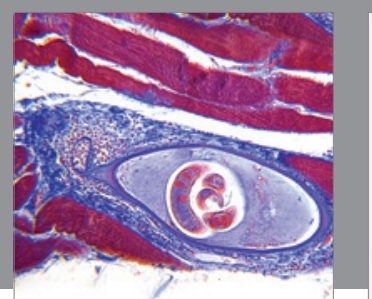

Gastroenterology Research and Practice

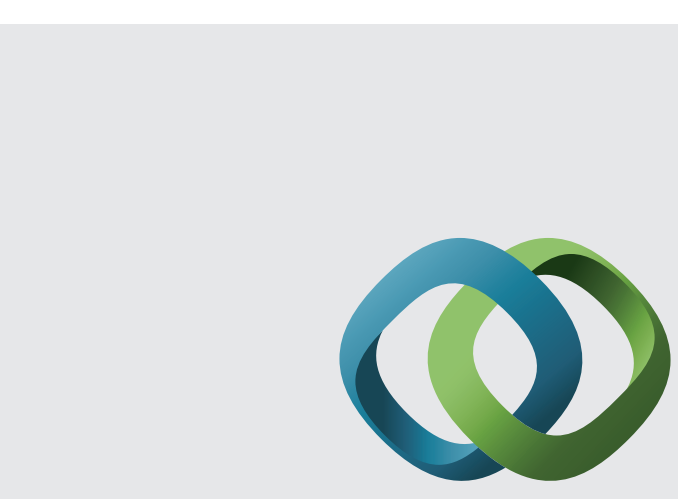

\section{Hindawi}

Submit your manuscripts at

http://www.hindawi.com
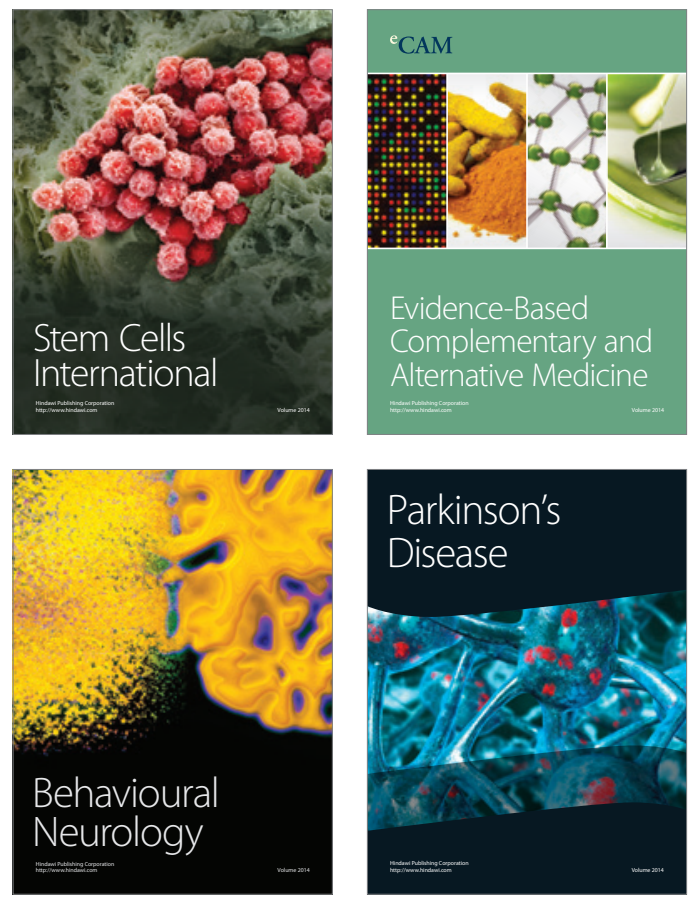
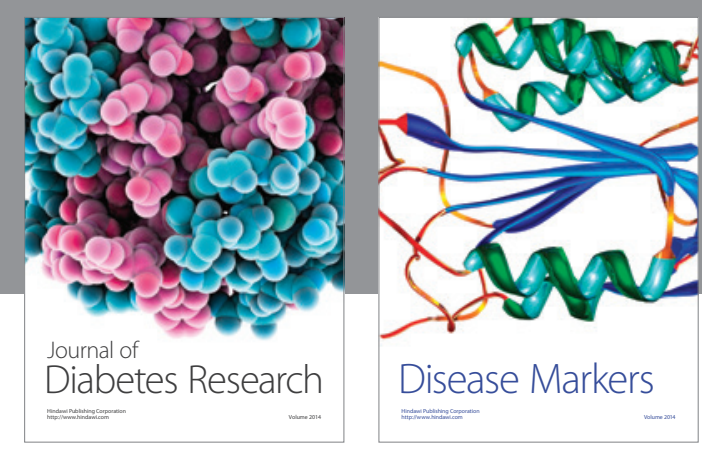

Disease Markers
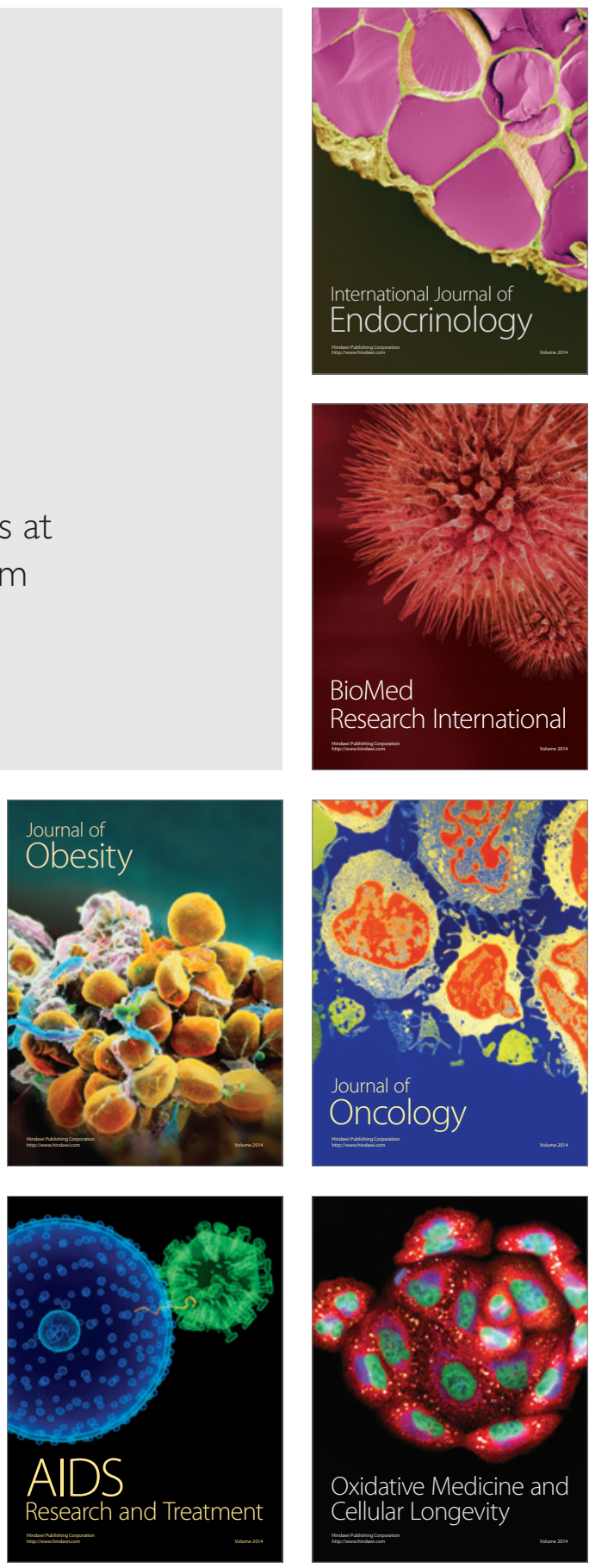